\title{
Secretin-like Activity of Dopamine on Canine Pancreatic Secretion
}

\author{
Yasuhiko Furuta, Kazuhiko Imatsuki, Osamu Takeuchi \\ and Koroku Hashimoto \\ Department of Pharmacology, Tohoku University School of \\ Medicine, Sendai
}

\begin{abstract}
Furuta, Y., Iwatsuki, K., Takeuchi, O. and Hashimoto, K. Secretinlike Activity of Dopamine on Canine Pancreatic Secretion. Tohoku J. exp. Med., $1972,108(4), 353-360$ - The composition of the pancreatic secretion was analyzed when the secretion was increased by intravenous infusions of dopamine from 0.03 to $0.5 \mathrm{mg} / \mathrm{min}$, highly purified secretin (Jorpes) from 0.03 to $0.5 \mathrm{U} / \mathrm{min}$ and pancreozymin (Boots) from 0.03 to $0.5 \mathrm{U} / \mathrm{min}$ in dogs. Dopamine and secretin caused the production of a large volume of juice containing a high concentration of bicarbonate but had little effect on protein output. On the other hand, pancreozymin caused a marked increase in output of total protein but little increase in the secretion and bicarbonate concentration. The effects of dopamine from 0.03 to $0.5 \mathrm{mg} / \mathrm{min} i . v$. on the secretory volume and the bicarbonate excretion roughly corresponded to those of secretin from 0.03 to $0.5 \mathrm{U} / \mathrm{min} i, v$. The activities of lipase, amylase and trypsin per unit volume $(=1 \mathrm{ml})$ of the juice obtained with pancreozymin $(0.3$ to $0.5 \mathrm{U} / \mathrm{min})$ were higher than those with either dopamine $(0.3$ to $0.5 \mathrm{mg} / \mathrm{min})$ or secretin $(0.3$ to $0.5 \mathrm{U} / \mathrm{min})$. These experiments show that dopamine has a secretin-like action on the pancreatic secretion. - pancreatic secretion; dopamine
\end{abstract}

It is well known that dopamine is a precursor of norepinephrine and it has a weak but definite adrenergic effect. Recently it was reported that dopamine has some different characters from other catecholamines in systemic blood pressure response (Hornykiewicz 1958, Burn and Rand 1958, McDonald and Goldberg 1963, Eble 1964), in the renal blood flow (McNay et al. 1965, Yeh et al. 1969), in the mesenteric vascular bed (Eble 1964, Yeh et al. 1969) and in the coronary circulation (Schuelke et al. 1971). Previously Greengard et al. (1942, 1944) observed that dopamine and epinine stimulated pancreatic secretion but norepinephrine inhibited it. They reported that epinine had a similar action to "a potent secretin concentrate" which contained both secretin and pancreozymin.

The recent reports by Takeuchi et al. (1971) and Hashimoto et al. (1971) in the isolated and blood perfused dog pancreas with intact innervation showed that a close intra-arterial or intravenous injection of dopamine caused a marked pancreatic secretion and the effect was never modified by $\alpha$ - and $\beta$-adrenergic blockers or atropine. They suggested that the effect of dopamine on the pancreatic secretion was direct action on the exocrine cells, but not through adrenergic

Received for publication, April 20, 1972. 
mechanism.

In order to study the characteristics of effects of dopamine on the pancreatic secretion, the volume of secretion, the concentrations of bicarbonate and chloride, total protein output and amylase, lipase and trypsin activities of the juice induced by an intravenous infusion of dopamine were compared with those of highly purified secretin (Jorpes) and pancreozymin.

\section{Methods}

Fifteen adult mongrel dogs of either sex, weighing from 10 to $15 \mathrm{~kg}$, were used. Animals were anesthetized initially with an intravenous injection of $30 \mathrm{mg} / \mathrm{kg}$ sodium pentobarbital, and anesthesia was maintained by additional intramuscular injections of $10 \mathrm{mg} / \mathrm{kg}$ at one hour intervals. The trachea was cannulated and a positive pressure respiration was performed by a respirator (Aika $R-50$ ). The abdomen was opened by a median incision and the main pancreatic duct was carefully isolated from the duodenum. The duodenal wall was incised longitudinally and a polyethylene tube, 0.8 $\mathrm{mm}$ i.d., was inserted through the papilla into the main pancreatic duct. The tube was connected to a drop counter. The accessory panereatic duct was ligated. The femoral vein was cannulated and Ringer's solution was infused at a constant rate of approximately $0.7 \mathrm{ml} / \mathrm{min}$ throughout experimental course. Each secretogogue was dissolved in $0.9 \%$ saline solution. Dopamine was infused at rates of $0.03,0.1,0.3$ and $0.5 \mathrm{mg}$ per min, secretin at $0.03,0.1,0.3$ and 0.5 clinical units (Jorpes and Mutt 1966) per min, and pancreozymin at $0.03,0.1,0.3$ and 0.5 Boots units (Crick et al. 1950) per min into the cannulated femoral vein by means of a Harvard infusion pump (Model 600 900) for 40 to $60 \mathrm{~min}$. A higher infusion rate of dopamine over this range was not tested because the systemic blood pressure was elevated and the initial increase of pancreatic secretion was reduced reversely afterward. Systemic blood pressure was recorded from the femoral artery by a pressure transducer (Nihon Kohden RP-2). After the secretogogue-induced flow rate became constant, a sample of pancreatic juice was collected for $15 \mathrm{~min}$ and immediately frozen in a deep-freezer for protein and enzyme assays. Subsequently, an adequate volume of sample in order to measure the concentration of bicarbonate was collected in the tube under $1 \mathrm{ml}$ of liquid paraffin.

The volume of the pancreatic juice was determined by a measuring cylinder in $\mathrm{ml}$ per $15 \mathrm{~min}$. The concentration of bicarbonate in $\mathrm{mEq} / \mathrm{liter}$ was measured by using a Natelson method (Natelson 1951) which was a modified Van Slyke manometric technique. Protein concentration was estimated by reading the optical density at $280 \mathrm{~m} \mu$ in a spectrophotometer (Hitachi Model 139) after diluting the juice with distilled water to $\mathbf{1}$ : 100 or $1: 300$. Bovine serum albumin (Wako) was used for the standard solution, and protein output was expressed as $\mathrm{mg}$ per $15 \mathrm{~min}$. Amylase activity was determined by a Caraway's method (Caraway 1959), and given in amylase units per ml of pancreatic juice. The amylase unit is defined as the amount of enzyme that will hydrolyze $10 \mathrm{mg}$ of starch in $30 \mathrm{~min}$ at $37^{\circ} \mathrm{C}$. Trypsin was measured with a Radiometer pH-stat apparatus as the number of micromoles of $\mathrm{NaOH}$ per min required just to neutralize the acid split from $a$ benzoyl-L-arginine ethylester hydrochloride (Sigma) at $25^{\circ} \mathrm{C}$, and $\mathrm{pH} 7.9$, in the presence of $1 \mathrm{ml}$ of pancreatic juice. Lipase was also measured with the $\mathrm{pH}$-stat as the number of micromoles per min of $\mathrm{NaOH}$ required to keep a mixture of olive oil substrate $(5 \%$ acid free olive oil in tris buffer) and $\mathrm{I} \mathrm{ml}$ of pancreatic juice at $\mathrm{pH}$ 8.1. In Figures, each enzyme output was given in units per $15 \mathrm{~min}$. Chloride concentration in $\mathrm{mE} /$ /liter was determined by the ultramicro-adaptation with Beckman 153 microtitrator method (Schales and Schales 1941).

Drugs used were dopamine hydrochloride (ICN), highly purified secretin (kindly given from Professor J.E. Jorpes, Karolinska Institutet, Stockholm, Sweden) and pancreozymin (Boots). 


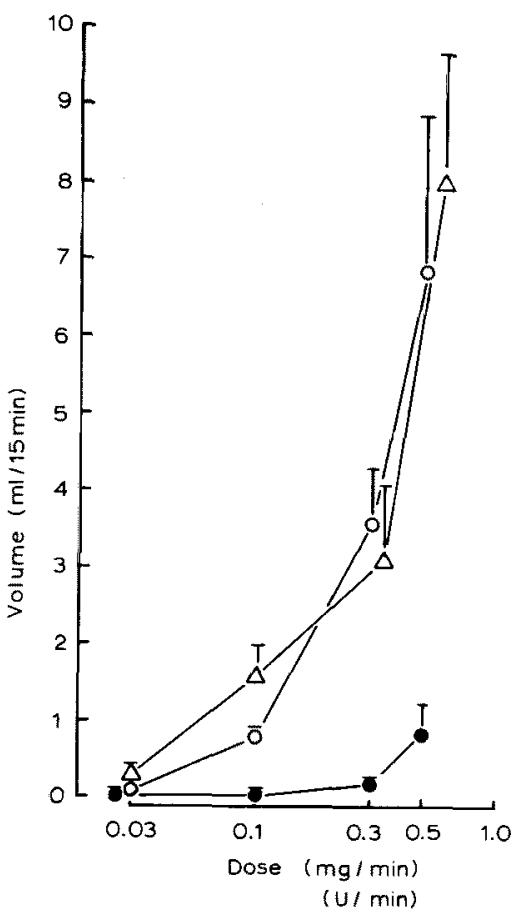

Fig. 1

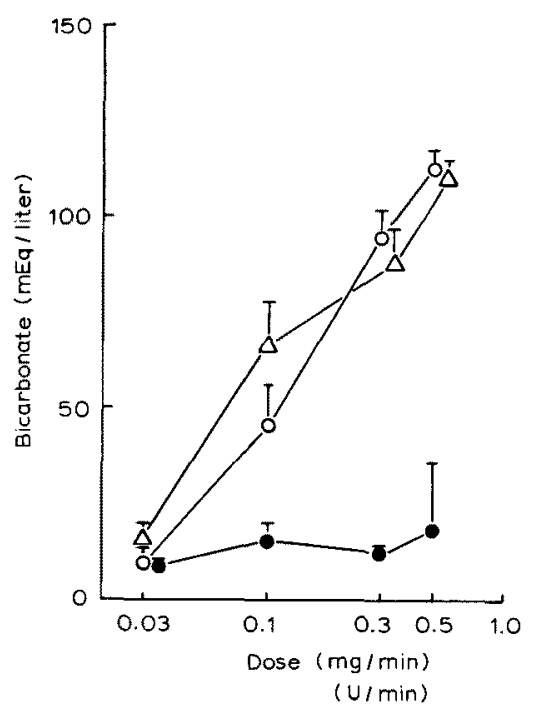

Fig. 2

Fig. 1. Dose-response curves for volume of pancreatic secretion in response to i.v. infusions of secretin, $\mathrm{U} / \mathrm{min},(\circ-)$; dopamine, $\mathrm{mg} / \mathrm{min},(\Delta-\Delta)$; and pancreozymin, U/min, (- - -). Each point represents mean of 5 experiments in 5 dogs and vertical bars indicate standard errors of the mean.

Fig. 2. Dose-reponse curves for concentration of bicarbonate in response to i.v. infusions of secretin, $\mathrm{U} / \mathrm{min},(-\infty)$; dopamine, $\mathrm{mg} / \mathrm{min},(\Delta-\Delta)$; and pancreozymin, $\mathrm{U} / \mathrm{min}$, (-). Each point represents mean of 5 experiments in 5 dogs and vertical bars indicate standard errors of the mean.

\section{Results}

1) Volume (Fig. 1).

The effect of dopamine causing an increase in volume of pancreatic secretion per $15 \mathrm{~min}$ was compared with those of secretin and pancreozymin which were well-known pancreatic secretogogues. Fig. 1 shows dose-response curves for three substances. A dose of $0.03 \mathrm{mg} / \mathrm{min}$ of dopamine or $0.03 \mathrm{U} / \mathrm{min}$ of secretin or pancreozymin never caused pancreatic secretion over the resting level. With increasing doses of dopamine and secretin definitely increased the volume of juice, while pancreozymin hardly increased it. In increasing the volume of pancreatic secretion the effect of $0.5 \mathrm{mg} / \mathrm{min}$ of dopamine was approximately equal to that of $0.5 \mathrm{U} / \mathrm{min}$ of secretin, as shown in Fig. 1.

2) Bicarbonate and chloride (Fig. 2; Table 1).

Dopamine caused dose-dependently a marked increase in a bicarbonate 
TABLE 1. Concentrations of bicarbonate and chloride ( $m E q /$ liter) in the secretion obtained with secretogogues

\begin{tabular}{|c|c|c|c|c|c|}
\hline $\begin{array}{c}\text { Dose } \\
\text { Secreto- } \\
\text { gogues }\end{array}$ & & 0.03 & 0.1 & 0.3 & 0.5 \\
\hline Secretin & $\begin{array}{c}\mathrm{HCO}_{3} \\
\mathrm{Cl}\end{array}$ & $\begin{array}{l}10 \pm 4 \dagger \\
141 \pm 5\end{array}$ & $\begin{array}{l}46 \pm 10 \\
132 \pm 7\end{array}$ & $\begin{array}{l}95 \pm 7 \\
82 \pm 16\end{array}$ & $\begin{array}{r}113 \pm 5 \\
51 \pm 12\end{array}$ \\
\hline Dopamine & $\begin{array}{c}\mathrm{HCO}_{3} \\
\text { Cl }\end{array}$ & $\begin{array}{r}16 \pm 4 \\
130 \pm 14\end{array}$ & $\begin{array}{l}67 \pm 11 \\
71 \pm 9\end{array}$ & $\begin{array}{l}88 \pm 9 \\
34 \pm 11\end{array}$ & $\begin{array}{r}111 \pm 5 \\
52 \pm 13\end{array}$ \\
\hline $\begin{array}{c}\text { Pancreo- } \\
\text { zymin }\end{array}$ & $\begin{array}{c}\mathrm{HCO}_{3} \\
\mathrm{Cl}\end{array}$ & $\begin{array}{r}9 \pm 3 \\
111 \pm 3\end{array}$ & $\begin{array}{r}15 \pm 5 \\
132 \pm 9\end{array}$ & $\begin{array}{r}23 \pm 11 \\
129 \pm 10\end{array}$ & $\begin{array}{l}45 \pm 21 \\
97 \pm 16\end{array}$ \\
\hline
\end{tabular}

* Dopamine $\mathrm{mg} / \mathrm{min}$, secretin and pancreozymin U/min, i.v.

$\uparrow$ Mean \pm s.

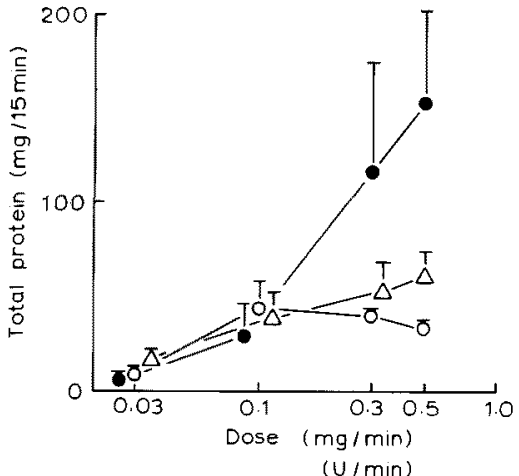

Fig. 3

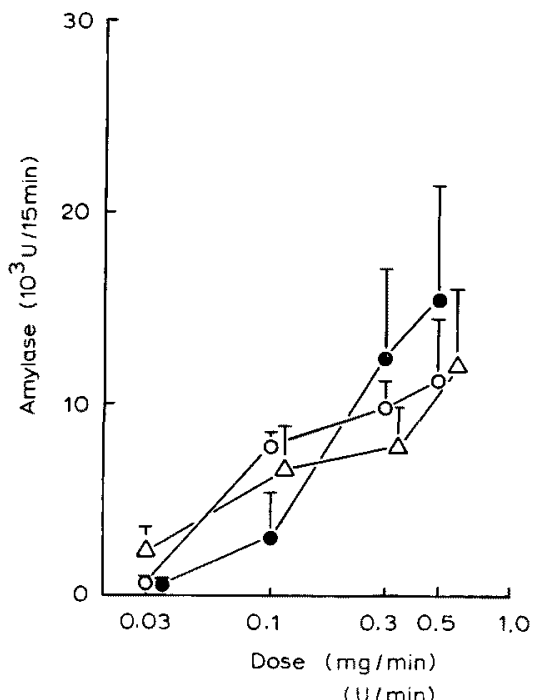

Fig. 4

Fig. 3. Dose-response curves for total protein output in response to i.v. infusions of secre-

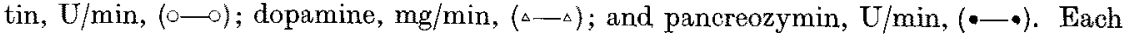
point represents mean of 5 experiments in 5 dogs and vertical bars indicate standard errors of the mean.

Fig. 4. Dose-response curves for amylase output in response to i.v. infusions of secretin,

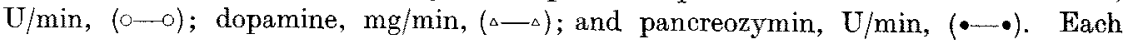
point represents mean of 5 dogs and vertical bars indicate standard errors of the mean.

concentration as shown in Fig. 2 and Table 1. The rate of increase obtained with dopamine was very similar to that with secretin. However, an infusion of pancreozymin showed little increase in the concentration of bicarbonate. The effect of $0.5 \mathrm{mg} / \mathrm{min}$ of dopamine causing bicarbonate secretion approximately corresponded to that of $0.5 \mathrm{U} / \mathrm{min}$ of secretin. The concentration of chloride varied conversely with that of bicarbonate as shown in Table 1. 


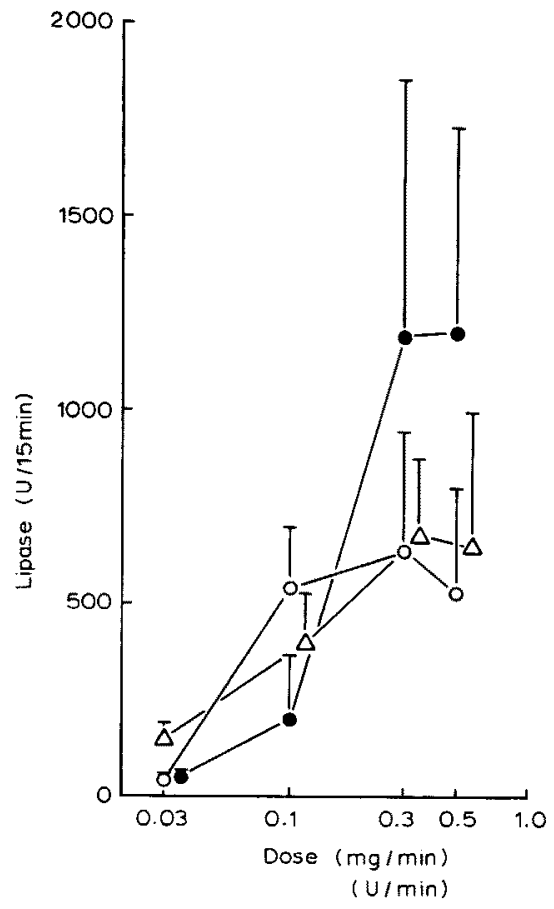

Fig. 5

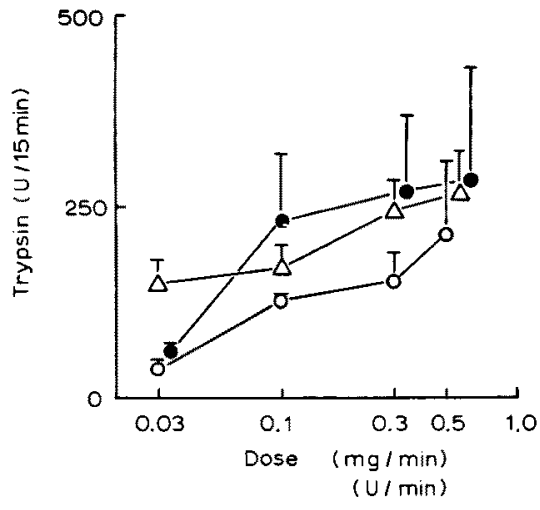

Fig. 6

Fig. 5. Dose-reponse curves for lipase output in response to i.v. infusions of secretin, U/

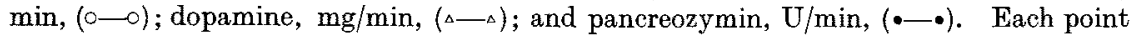
represents mean of 5 experiments in 5 dogs and vertical bars indicate standard errors of the mean.

Fig. 6. Dose-response curves for trypsin output in response to i.v. infusions of secretin, $\mathrm{U} / \mathrm{min},(\circ-0)$; dopamine, $\mathrm{mg} / \mathrm{mind},(\Delta-\Delta)$; and pancreozymin, U/min, (•-). Each point represents mean of 5 experiments in 5 dogs and vertical bars indicate standard errors of the mean.

\section{3) Total protein (Fig. 3).}

Total protein output induced for $15 \mathrm{~min}$ by each substance was shown in Fig. 3. Either dopamine or secretin caused a slight increase in protein output, while pancreozymin caused a marked increase in comparison with dopamine and secretin.

4) Enzyme activities (Figs. 4, 5 and 6; Table 2).

Figs. 4, 5 and 6, and Table 2 show changes in amylase, lipase and trypsin activities of the pancreatic juice secreted in response to dopamine, secretin and pancreozymin. The enzyme activities per unit volume obtained with increasing doses of dopamine or secretin fell to a lower level, but those with pancreozymin were not so significantly changed (Table 2). However, the enzyme output per 15 min was increased by all of the three secretogogues (Figs. 4, 5 and 6). 
TABLE 2. Enzyme activities per unit volume in the secretion obtained with secretogogues

\begin{tabular}{|c|c|c|c|c|c|}
\hline & $\begin{array}{l}\text { Dosereto- } \\
\text { gogues }\end{array}$ & 0.03 & 0.1 & 0.3 & 0.5 \\
\hline $\begin{array}{l}\text { Amylase } \\
(10 \times \mathrm{U})\end{array}$ & $\begin{array}{l}\text { Secretin } \\
\text { Dopamine } \\
\text { Pancreozymin }\end{array}$ & $\begin{array}{l}727 \pm 21 \dagger \\
436 \pm 99 \\
728 \pm 37\end{array}$ & $\begin{array}{r}1049 \pm 290 \\
343 \pm 105 \\
524 \pm 155\end{array}$ & $\begin{array}{l}302 \pm 89 \\
218 \pm 86 \\
616 \pm 39\end{array}$ & $\begin{array}{l}166 \pm 10 \\
236 \pm 52 \ddagger \\
607 \pm 69\end{array}$ \\
\hline $\begin{array}{l}\text { Trypsin } \\
\text { (U) }\end{array}$ & $\begin{array}{l}\text { Secretin } \\
\text { Dopamine } \\
\text { Pancreozymin }\end{array}$ & $\begin{array}{l}456 \pm 60 \\
562 \pm 208 \\
578 \pm 73\end{array}$ & $\begin{array}{r}172 \pm 40 \\
90 \pm 24 \\
507 \pm 193\end{array}$ & $\begin{array}{r}44 \pm 8 \\
80 \pm 26 \\
850 \pm 417\end{array}$ & $\begin{array}{c}29 \pm 4 \\
40 \pm 8 \\
345 \pm 145\end{array}$ \\
\hline $\begin{array}{c}\text { Lipase } \\
\text { (U) }\end{array}$ & $\begin{array}{l}\text { Secretin } \\
\text { Dopamine } \\
\text { Pancreozymin }\end{array}$ & $\begin{array}{l}524 \pm 133 \\
360 \pm 74 \\
796 \pm 492\end{array}$ & $\begin{array}{r}783 \pm 345 \\
193 \pm 49 \\
1121 \pm 200\end{array}$ & $\begin{array}{l}242 \pm 157 \\
154 \pm 21 \\
680 \pm 204\end{array}$ & $\begin{array}{r}70 \pm 19 \\
70 \pm 25 \\
533 \pm 239\end{array}$ \\
\hline
\end{tabular}

\section{Discussion}

The secretogogue effect of sympathomimetic amines on the pancreas was first examined by Greengard et al. in 1942. They observed that intravenous injections of epinine, $m$-hydroxyphenethylamine and dopamine stimulated the canine pancreas to secrete the juice, although that of norepinephrine, epinephrine and other 22 compounds did not do it. Recently, the specificity of dopamine as secretogogue was confirmed in the isolated and blood perfused dog pancreas preparations by Takeuchi et al. (1971) and Hashimoto et al. (1971). They reported that a close intra-arterial injection of $3 \mu \mathrm{g}$ of dopamine caused secretion of a large quantity of pancreatic juice which was equal to that obtained with 0.1 unit of secretin (Boots), and the effect of dopamine was never modified by propranolol, phenoxybenzamine or atropine at a dose which inhibited vascular responses to isoproterenol, epinephrine or acetylcholine, respectively. L-Dopa induced a profuse secretion of pancreatic juice with a few minutes delay by an intra-arterial infusion. From these results, they proposed that dopamine may have a physiological role in pancreatic secretion.

A large quantity of pancreatic juice induced by dopamine contained a high concentration of bicarbonate and a low concentration of chloride. These effects of dopamine from 0.03 to $0.5 \mathrm{mg} / \mathrm{min}$ were very similar to those of secretin (Jorpes) from 0.03 to $0.5 \mathrm{U} / \mathrm{min}$. The difference in relative potencies of dopamine and secretin is observed between close intra-arterial and intravenous infusion methods which will be ascribed to quick destruction of dopamine by the systemic administration. Pancreozymin caused a high protein output with high enzyme activities per unit volume in amylase, lipase and trypsin, although it increased slightly the volume and concentration of bicarbonate in a higher dose. Either increasing doses 
of secretin or dopamine did not cause a significant increase in protein output with lower enzyme activities per unit volume.

From these, it is concluded that the mode of action of dopamine causing pancreatic secretion is a very similar to that of secretin. Considering previous observations on the presence of dopamine in the pancreas more than $50 \%$ of the total catecholamines (Schümann and Heller 1959) and on turnover to dopamine after uptake of L-dopa in acinus cells (Alm et al. 1969), dopamine may probably contribute to pancreatic secretion as physiological secretogogue, but the relation between secretin and dopamine is not elucidated yet.

\section{Acknowledgment}

We express many thanks to Professor J.E. Jorpes for giving us highly purified secretin sample. These experiments were performed with grant of Kanae's Medical Bounty, Inc.

\section{References}

1) Alm, P., Ehinger, B. \& Falek, B. (1969) Histochemical studies on the metabolism of L-dopa and some related substances in the exocrine pancreas. Acta physiol. scand., 76, 106-120.

2) Burn, J.H. \& Rand, M.J. (I958) The depressor action of dopamine and adrenaline. Brit. J. Pharmacol., 13, 471-479.

3) Caraway, W.T. (1959) A stable starch substrate for the determination of amylase in serum and other body fluids. Amer. J. clin. Path., 32, 97 99.

4) Crick, J., Harper, A.A. \& Raper, H.S. (1950) On the preparation of secretin and pancreozymin. J. Physiol. (Lond.), 110, 367-376.

5) Eble, J.N. (1964) A proposed mechanism for the depressor effect of dapamine in the anesthetized dog. J. Pharmacol. exp. Ther., 145, 64-70.

6) Greengard, H., Grossman, M.I., Roback, R.A. \& Ivy, A.C. (1944) The enzyme content of pancreatic secretion following various stimulants. Amer. J. Physiol., 141, $509-512$.

7) Greengard, H., Roback, R.A. \& Ivy, A.C. (1942) The effect of sympathomimetic amines on pancreatic secretion. J. Pharmacol. exp. Ther., 74, 309-318.

8) Hashimoto, K., Satoh, S. \& Takeuchi, O. (1971) Effect of dapamine on pancreatic secretion in the dog. Brit. J. Pharmacol., 43, 739-746.

9) Hornykiewicz, $0 .(1958)$ The action of dopamine on the arterial blood pressure of the guinea-pig. Brit. J. Pharmacol., 13, 91-94.

10) Jorpes, J.E. \& Mutt, V. (1966) On the biological assay of secretin. The reference standard. Acta physiol. scand., 66, 316-325.

11) McDonald, R.H. \& Goldberg, L.I. (1963) Analysis of the cardiovascular effects of dopamine in the dog. J. Pharmacol. exp. Ther., 140, 60-66.

12) MeNay, J.L., McDonald, P.H. \& Goldberg, L.T. (1965) Direct renal vasodilatation produced by dopamine in the dog. Circulat. Res., 16, 510-517.

13) Natelson, S. (1951) Routine use of ultramicro methods in the clinical laboratory. Amer. J. clin. Path., 21, 1153-1172.

14) Schales, O. \& Schales, S.S. (1941) A simple and accurate method for the determination of chloride in biological fluids. J. biol. Chem., 140, 879-884.

15) Sehuelke, D.M., Mark, A.L., Schmid, P.G. \& Eckstein, J.W. (1971) Coronary vasodilatation produced by dopamine after adrenergic blockade. J. Pharmacol. exp. Ther., 176, 320-327.

16) Schümann, H.J. \& Heller, I. (1959) Uber den Hydroxytyramingehalt der Organe. Arch. exp. Path. Pharmak, 236, 474-482.

17) Takeuchi, O., Satoh, S. \& Hashimoto, K. (1971) Role of dopamine in the secretory 
mechanism of the canine pancreas. Tohoku J. exp. Med., 104, 203-204.

18) Yeh, B.K., MoNay, J.L. \& Goldberg, L.I. (1969) Attenuation of dopamine renal and mesenteric vasodilation by haloperidol: Evidence for a specific dopamine receptor. J. Pharmacol. exp. Ther., 168, 303-309. 